ISSN: $1412-4734$

E-ISSN: 2407-8646

Volume 18, Number 1, 2018

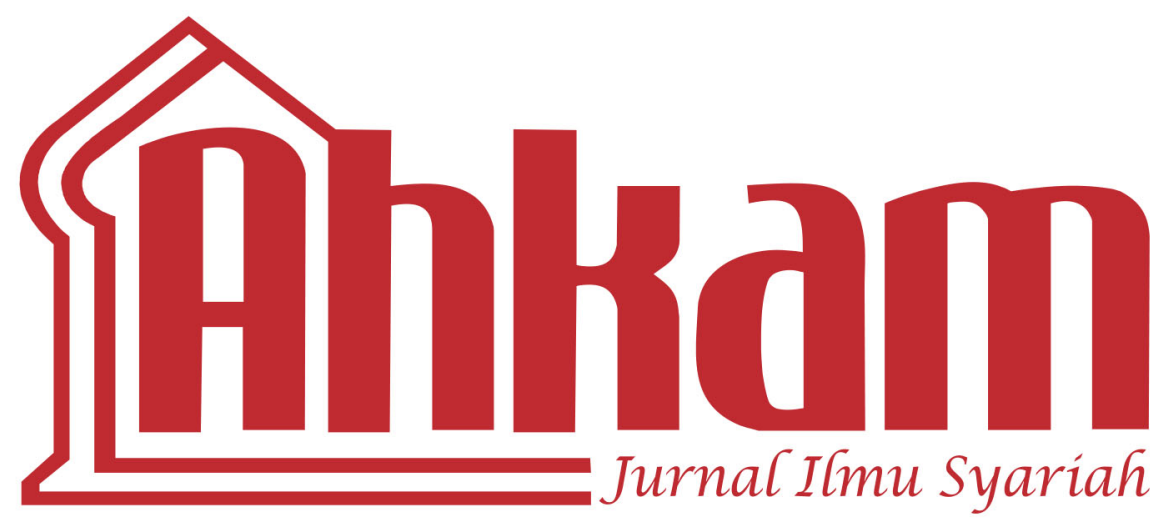

* Herdi Sahrasad \& Al Chaidar

Indonesian Terrorist, ISIS, and Globalization of Terror: A Perspective

* Hotnidah Nasution

Implementation of the Principle of Ultra Petitum Partium in Deciding Children Livelihood in Divorce Lawsuit in Religious Courts

* Havis Aravik, Choiriyah \& Saprida

Critical Study on the Legal Thinking of Muhammad Shahrur

* Nita Triana

Urgency of Arbitration Clause in Determining the Resolution of Sharia Economic Disputes

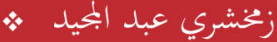

أهمية قوانين المصارف الشرعية في إنلدونيسيا (نظرية التقسير الموضوعى)

* Arrisman

Islamic Law And Business Ethics: Case Study of Forest Fires for Clearing the Lands 


\section{Mhliam}

Volume 18, Number 1, 2018

EDITOR-IN-CHIEF

Khamami Zada

EDITORS

Fathudin

Maman R Hakim

Windy Triana

Nur Hidayah

Ahmad Bahtiar

INTERNATIONAL EDITORIAL BOARD

Tim Lindsey (University of Melbourne Australia)

Nadirsyah Hosen (Monash University Australia)

Ahmad Hidayat Buang (Universiti Malaya Malaysia)

Raihanah Azahari (University Malay Malaysia)

Mark Elwen Cammack (Southwestern University)

Razeen Sappideen (University of Western Sydney)

Carolyn Sappideen (University of Western Sydney)

Nik Ahmad Kamal bin Nik Mahmod (International Islamic Universiti Malaysia)

Ahmad Tholabi Kharlie (UIN Syarif Hidayatullah Jakarta)

Muhammad Atho Mudzhar (UIN Syarif Hidayatullah Jakarta)

Masykuri Abdillah (UIN Syarif Hidayatullah Jakarta)

Muhammad Amin Suma (UIN Syarif Hidayatullah Jakarta)

M. Arsykal Salim GP (UIN Syarif Hidayatullah Jakarta)

Asep Saepudin Jahar (UIN Syarif Hidayatullah Jakarta)

ASSISTANT TO THE EDITORS

Kamal F. Musa

Erwin Hikmatiar

ENGLISH LANGUAGE ADVISOR

Bradley Holland

Umi Kulsum

ARABIC LANGUAGE ADVISOR

Amany Burhanudin Lubis

AHKAM has been accredited based on the determination of Director General of Research Reinforcement and Development, Research, and Technology Ministry of Higher Education of Republic of Indonesia, No. 36/a/E/KPT/2016 (valid until 2021). 
AHKAM Jurnal Ilmu Syariah (ISSN: 1412-4734) is a periodical scientific journal published by Faculty of Sharia and Law of Syarif Hidayatullah State Islamic University Jakarta in collaboration with Indonesian Scientist and Sharia Scholar Association (HISSI). This journal specifically examines the science of sharia and obtains to present various results of current and eminence scientific research. The administrators receive articles as contributions Sharia and Islamic law disciplines from scientists, scholars, professionals, and researchers to be published and disseminated.

\section{EDITORIAL OFFICE:}

Fakultas Syariah dan Hukum UIN Syarif Hidayatullah Jakarta

Jl. Ir. H. Juanda 95 Ciputat, Jakarta 15412

Telp. (+62-21) 74711537, Faks. (+62-21) 7491821

Website: http://journal.uinjkt.ac.id/index.php/ahkam/index

E-mail: Jurnal.ahkam@uinjkt.ac.id 


\section{Table of Contents}

1 Herdi Sahrasad \& Al Chaidar

Indonesian Terrorist, ISIS, and Globalization of Terror:

A Perspective

23 Hotnidah Nasution

Implementation of the Principle of Ultra Petitum Partium in Deciding Children Livelihood in Divorce Lawsuit in Religious Courts

43 Havis Aravik, Choiriyah \& Saprida

Critical Study on The Legal Thinking of Muhammad Shahrur

65 Nita Triana

Urgency of Arbitration Clause in Determining The Resolution of Sharia Economic Disputes

89

زخشري عبد المجيد

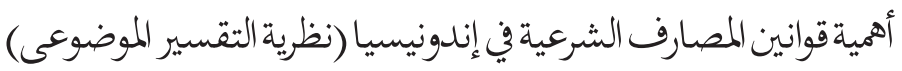


109 Arrisman

Islamic Law and Business Ethics: Case Study of Forest Fires for Clearing The Lands

125 Abdulmajeed Hassan-Bello

Riba and Islamic Banking, Examining the Practices of Jaiz Bank PLC, Nigeria

155 ISNaWATI Rais

Marriage Dispensation due to Extramarital Pregnancy: The Study on the Decision by the Religious Court of South Jakarta (2010-2011)

177 HaMZAH

Zakah Empowerment Optimization Through Baitul Ikhtiar Cooperation as an Effort in Poverty Alleviation in Bogor Regency

201 Abdul Muta'Ali

Israel and Palestine Conflict from Linguistics and Figh

Siyasah Perspective

219 Susiknan Azhari

Tracing the Concept of Fajr in the Islam Mosaic and Modern Science

233 Ahmad Sholihin Siregar

The Construction of Āyātul Aḥkām (Constructing the Selection Bases of Āyātul Aḅkàm) 


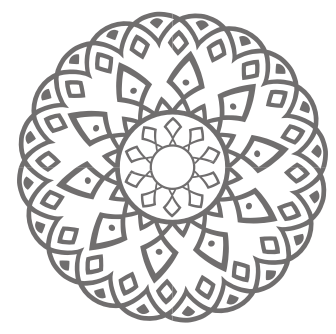

\title{
Urgency of Arbitration Clause in Determining the Resolution of Sharia ECONOMIC Disputes
}

\author{
Nita Triana
}

\begin{abstract}
Abstrak: Studi ini menjelaskan pentingnya klausula arbitrase dalam menentukan metode penyelesaian perselisihan ekonomi. Penyelesaian sengeta ekonomi melalui jalur litigasi di pengadilan kurang menarik minat para pelaku ekonomi, karena faktor waktu yang lama, terbatasnya sumberdaya dan hasilnya yang berupa menang-kalah yang menyebabkan rusaknya hubungan bisnis di masa yang akan datang. Penyelesaian melalui jalur arbitarse merupakan salah satu altenatif penyelesaian sengketa. Dengan menggunakan metode kualitatif, yaitu penelitian doktrinal dengan pendekatan hukum normative, studi ini akan menganalisa landasan hukum arbitrase untuk penyelesaian sengketa ekonomi dari perspketif hukum Islam dan Indonesia. Paper ini berargumen bahwa penyelesaian sengketa menggunakan arbitrase memiliki banyak manfaat dibandingkan litigasi (melalui pengadilan), karena sifatnya yang memprioritaskan negosiasi, menghindari permusuhan sehingga hubungan bisnis dapat tertap terjalin baik. Untuk mengantisipasi sengketa dalam kontrak komersial antara dua pihak, sangatlah penting untuk membuat klausula arbitase terpisah dari persetujuan komersial (persetujuan prinsipal). Klausula arbitrase harus ditekankan dalam kontrak-kontrak ekonomi syariah untuk mempercepat gerakan ekonomi syariah di masa yang akan datang.
\end{abstract}

Kata kunci: klausula arbitrase, penyelesaian sengketa, ekonomi syariah, tahkim, perdamaian. 
Abstract: This study explains the importance of the arbitration clause in determining the resolution of sharia economic disputes. The settlement of economic disputes in the Court is less in the interest of the economic actors, because of the long time, the limited resources and the results of the win-loss cause damage to future business relations. Resolution of arbitration disputes is an alternative choice. Using qualitative method, a type of doctrinal research with a normative juridical approach, this study will analyze the legal basis of arbitration of economic dispute from Islamic and Indonesian legal perspectives. It is argued that dispute resolution using arbitration has many advantages over litigation (Court), dues to its the nature of prioritizing negotiations, avoiding hostility so that business relationships will still be intertwined properly. Anticipating a dispute in a commercial agreement between the two parties, it is important to make an arbitration clause separate from the commercial agreement (principal agreement). The arbitration clause is binding on both parties. Arbitration caluses (*clauses) should be emphasized in economic sharia contracts to accelerate the movement of the sharia economy in the future.

Keywords: arbitration clause, dispute resolution, sharia economic, tahkim, feace

$$
\begin{aligned}
& \text { ملخص: تشرح هذه الدراسة عن أهمية بنود التحكيم في تحديد حل النزاعات الاقتصادية }
\end{aligned}
$$

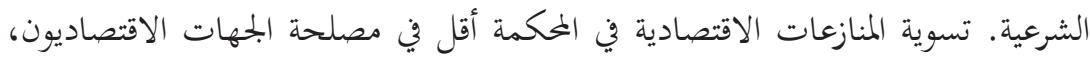

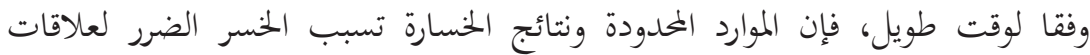

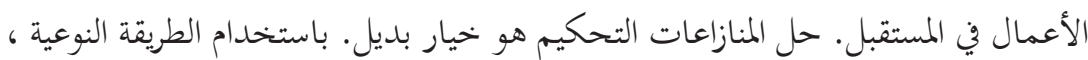

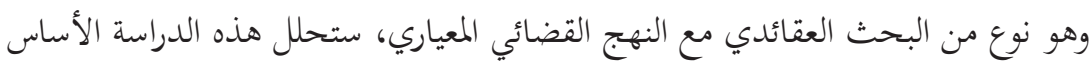

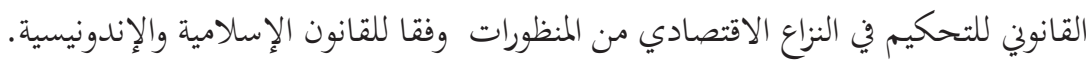

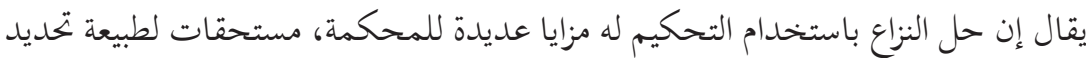

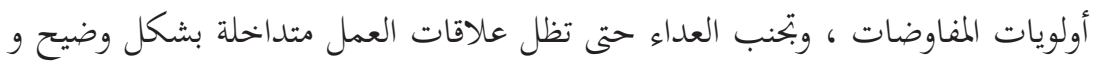

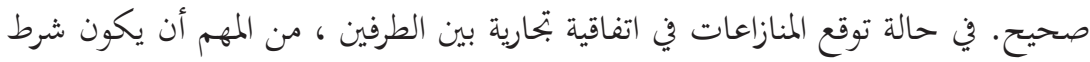

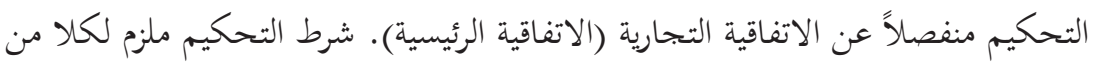

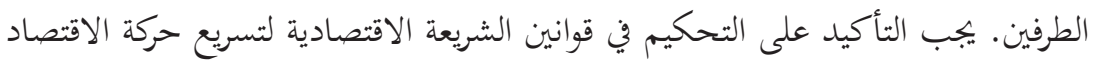

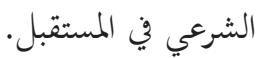

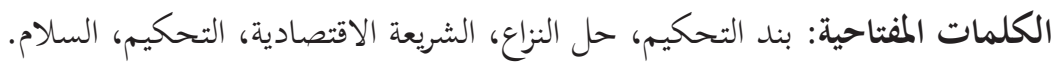




\section{Introduction}

Sharia financial institutions that exist in Indonesia and in several Muslim countries have developed quite a lot. In Indonesia, it began with the promulgation of Law No.7 of 1990 concerning Banking, which among others stated that it was possible to establish a bank with a profit sharing system, so that the regulation became the basis for the establishment of Bank Muamalat Indonesia as the first bank in Indonesia to implement the sharia system. Then, the Act was amended by Law No.10 of 1988 concerning Banking, which has the opportunity to implement the dual banking system in this national banking system. So that the Act has encouraged the opening of the sharia division in a number of conventional banks.

Sharia-based financial institutions are not only developing in countries where the majority of the population is Muslim. There have been many Sharia banks in European countries and the United States. We can see Citibank that has established Citi Islamic Investment Bank. Likewise ABN Amro Bank with ABN Amro Global ANZ Global Islamic Financial Services and Investment Bank with First ANZ International Moderator. In addition, Standard Chartered Bank and Chase Manhattan Bank are examples of international giant financial institutions that have begun working on sharia banking. They not only target Muslim customers but also non-Muslims (Shandy Dwi Fernandi; https://shandydwifernandi.com/; downloaded on October 3, 2018).

With the development of Islamic financial institutions in the banking sector, sharia-based non-banking financial institutions have now been followed. Like sharia pawning, sharia insurance, sharia bonds and even the sharia capital market. These institutions were originally only established by countries with a majority Muslim community, but at present, the sharia financial industry is increasingly developing into western countries and non-Muslim countries. Even various financial centers of the world such as London, Singapore and Hong Kong launched themselves as International Islamic Financial Hubs. Countries in the Asian region that have high economic growth such as China, India and Japan have started issuing sukuk (sharia bonds) to finance infrastructure development and business development in their countries. 
Sharia economic relations which are national and international in nature, certainly cannot be separated from problems, which if not resolved will develop into disputes or conflicts. Although each community has its own way to resolve the dispute, the development of a globally and globally developing business world has begun to recognize homogeneous, peaceful, "profitable" forms of dispute resolution and provide a sense of "security" and justice for the parties.

One of the most popular and much in demand now is the way to resolve disputes through arbitration. Even now the developed world is reluctant to enter into business relations without being bound by an arbitration agreement. Indeed for the developed world, they have considered commercial arbitration a business executive's court as an alternative dispute resolution. When compared to resolving business disputes through formal justice, it generally takes a long time due to the fact that the procedures of the judicial system are very complex, and complicated. In addition, the business world thinks that the resolution of disputes in the business field is poorly understood by the Judges compared to those involved in the business world itself. In addition, the characteristics of arbitration that are not too formal so that this can be put motion quickly. and the nature of the decision is final and binding, because the arbitration award cannot appeal to the High Court, appeal to the Supreme Court, or Judicial review.

The substance of arbitration is an arbitration agreement. The arbitration agreement will determine whether a dispute can be resolved through arbitration, where it is settled, which law will be used and others. The arbitration agreement can be independent or separate from the principal agreement. The arbitration agreement must be carefully arranged, accurate and binding. The aim is to avoid the arbitration agreement used by one of the parties as a weakness that can be used to transfer the dispute to the court.

For this reason it is very interesting to analyze the urgency of the arbitration clause in the agreements in the multilateral field of sharia economics. And how the choice of resolution of arbitration disputes is seen from the perspective of Islamic law. 


\section{Discussion}

\section{Advantages of Arbitration as an Alternative Dispute Resolution}

Based on Law number 3 of 2006 concerning amendments to Law Number 7 of 1999 concerning Religious Courts. The scope of the authority to prosecute the environment of the Religious Courts reaches a wider scope, namely in the field of Sharia economics (Asnawi, 2011: 6), such as: sharia insurance, sharia reinsurance, sharia banking, sharia pawning, sharia financing, sharia securities, sharia mutual funds, bonds (sukuk) and sharia medium-term securities, sharia financial institutions pension funds, sharia microfinance institutions and various other sharia businesses. Religious Courts have some limitations in resolving sharia economic disputes (Manik et al, 2017: 439) including limited human resources with expertise in accordance with the development of Islamic economics. especially in the field of renewable sharia economics, such as sharia mutual funds, sharia bonds and sharia businesses related to agreements between countries.

The Religious Courts also have limitations in the number of Judges and Registrars. The IA class Religious Court, for example, has an average of 8 to 10 judges, while the cases examined each year range from 4000 cases. for example in the Cilacap Religious Court, each year the Religious Court examines around 6000 divorce cases. The number of cases in the Religious Courts resulted in a long settlement of the dispute in the Court (Triana, 2017: 108).

The nature of the Court which gives a win and lose decision can also cause hostility and damage future business relationships, one thing that is very avoided by business people. Besides that where the Islamic economy has moved between countries, the nature and system of the Court in a country will certainly be different from other countries. Therefore an institution and a dispute resolution system is needed that can be received by various parties between countries, such as arbitration.

Islam as a religion that loves peace more and becomes a guideline for its adherents, in the event that the muamalah dispute arises asserts that it will be more important if resolved through peaceful means ( tasaluh / Suluh). For this reason, the parties to the dispute should put forward more deliberation to reach consensus when facing a dispute. Through this dialogical effort, it is expected that existing business relations and 
brotherhood can remain intertwined and can better maintain good relations among the parties, and can be more economical in terms of time and cost. In the case of discussion for consensus, no new parties can be reached by other efforts, namely, through negotiation, mediation, arbitration, and litigation through the court as the last resort that can be taken by the parties to resolve the dispute.

Arbitration in Islamic law has long been known as a form of dispute resolution known as tahkim. This sentence in jurisprudence is discussed in general in the case of syiqaq (disputes) between husband and wife, as explained in QS. An-nisa: 35. Meaning: "If you are worried about a dispute between the two, then send a Hakam from the male family and a Hakam from a female family" . This verse expressly and textually only states the existence of the tahkim in the field of law.

According to Al-Munjid's dictionary, the tahkim is to appoint someone as a referee or peace agent. Whereas Salam Madkur stated in the book Al-Qadha Fil Islam that the term tahkim means to appoint someone or more as a referee or peace agent by two or more people who are in dispute in order to settle the case which they have divided peacefully. While the term now tahkim can be translated as arbitration, and the person acting as the referee is called arbitrator or hakam.

While other verses contained in the Al-Qur'an to be used as the basis for the execution of the tahkim or arbitration are QS. Al-Hujurat: 9, and QS. An-Nisa 'verses 114 and 128. From the verses above it can be stated that what is meant by Hakam in this verse is the peace between the two husband and wife who are in dispute. However, even if this basis is used to resolve disputes in other fields such as Islamic economics, it means that the method used is the interpretation of Analogy or Qiyas.

The above verse clearly shows that Allah SWT supports dispute resolution through tahkim (arbitration) and advises Muslims to choose someone as hakam in resolving their dispute. Although the first paragraph above is textually related to family matters, it is important to note that the tahkim is not solely used to settle family matters, but can also be used to resolve commercial, financial, banking and other civil disputes. . The Prophet Muhammad also clearly acknowledged the practice of tahkim. During the Prophet's lifetime, there were many instances where the Prophet himself practiced tahkim, and often acted 
as hakam (arbitrators) between individuals and Arab tribes in resolving their disputes.

According to Syed Khalid Rashid (2011: 23) see also Wahed (2015: 120) Islam encourages dispute resolution through tahkim (arbitration). In tahkim, the dispute resolution process is carried out informally, not technically, cheaply and quickly. Each party has the right to withdraw from the arbitration process before an award is given. If the parties have set a time limit for their convenience, it must be obeyed. The disputing party may appoint an arbitrator. Then, arbitrators in Islamic law are not bound by complicated procedures. If the settlement of a dispute is not reached, the arbitrator can give a legally binding decision to both parties. In giving a decision, the arbitrator is permitted to use his intuition based on fairness, fairness and equality (amiable composition) as long as it does not violate sharia principles or relevant customs rules in resolving disputes.

Based on the explanation above, tahkim is very useful in solving Islamic economic disputes. In completing the Islamic economy, individuals who are experts in their fields should be appointed so that the solution is more maximal and handled by individuals who are competent. At present, in several countries such as Indonesia and Malaysia have implemented arbitration based on sharia principles in order to resolve sharia economic disputes (Khalidah, 2012: 79).

Tahkim or Arbitration is one of the mechanisms based on mutual agreement, which can be used as a tool of peace to resolve a dispute that arises now and in the future (Zahraa, 2006: 4) see also (Zuhaili, 2005: 39). Arbitration serves as one of the Alternative Dispute Settlement so that it can be a solution for the settlement of national civil disputes in Indonesia or able to resolve civil disputes or disputes with the principle of prioritizing peace efforts or islah.

Formal juridical definition of arbitration is contained in Article 1 number (1) Law No. 30 of 1999 on Arbitration and Alternative Dispute Resolution (UUAPS) which reads: "Arbitration is a way of resolving a civil dispute outside the General Court based on an arbitration agreement made in writing by the parties to the dispute ".In addition to the Law No. 30 of 1999 on Arbitration and Alternative Dispute Resolution (UUAPS), arbitase is also regulated in more detail in Law No.48 of 2009 concerning Judicial Power, Article 59: (1). Arbitration is a way of resolving a civil 
dispute outside the court based on an arbitration agreement made in writing by the parties to the dispute, (2). The award is final and has permanent legal force and is binding on the parties, (3). In the event that the parties do not implement the arbitral award voluntarily, the decision is carried out based on the order of the chairman of the District Court at the request of one of the parties to the dispute.

Arbitration as an alternative dispute resolution is in great demand by business people because the arbitration procedural law which has many advantages over the Court, as follows (Kartuzov, 2015: 65):

(1) The Arbitrator Council that presides over the trial process is more flexible in determining the trial agenda by adjusting the interests of litigants. In each trial the arbitreir Council continues to seek mediation between the parties. The parties are given time to mediate, both inside and outside the trial. Even so the mediation process remains in the supervision of the Arbiteir Assembly so as not to be protracted without certainty of settlement.

(2) The choice of conducting a caucus (a separate meeting) is often carried out by the Arbitrator Council to find out more clearly the problem description of the parties. In this process, the parties have the discretion to discuss with the arbitrator council, especially the arbitrator council has read all the claim files (requests) and answers. On the other hand, the arbitrator is an expert in his field, so the discussion to technical issues to lead to the settlement can work well. Although not all cases can be resolved through mediation.

(3) Arbitration has timeliness on trial schedule. The trial schedule at BANI (Indonesian National Arbitration Board) can always be ascertained on time as previously scheduled. Even if there is a delay, the clerk will immediately inform the parties before the planned trial time. So that we will not feel disappointed and waste time waiting for the trial but it turns out the trial was postponed.

(4) Aspects of confidentiality (Yacob, 2009: 136) Its confidential nature makes arbitration seen as an alternative solution that suits the needs of the business world. This is because arbitration is held in a closed manner. Unlike the method of dispute resolution in the open public court, arbitration is only attended by interested parties or in other words the disputing parties. "No one else was present, no reporter could blow up the news. The correspondence is also all confidential, "This made the disputing parties feel more comfortable. In the business world, news related to business disputes from a company will result in the emergence of precedents against the parties to the dispute. 
(5) Dispute resolution through arbitration is handled by an arbitrator who does have expertise and competence in the business field which is the subject of the case. In Article 12 paragraph (1) letter e UUAPS is determined one of the conditions for being able to be appointed as an arbitrator, namely having experience and actively mastering in his field for at least 15 years. Thus it can be ascertained, the arbitrator has sufficient knowledge and understanding related to the business related to the case he will handle.

Arbitration can be led by a single arbitrator or arbitrator assembly. In the case of settlement of a dispute at BANI (Indonesian National Arbitration Board), if the parties do not determine in advance about the number of arbitrators, then the Chairperson of BANI has the right to decide whether the dispute is resolved by a single arbitrator or assembly based on the nature and complexity of the dispute and / or the scale of the dispute concerned or the value of the claim disputed in such a way as to its size or nature so that it requires an Assembly consisting of three arbitrators. But generally the practices that have been valid at BANI, the trials at BANI are led by the Arbitrator Council.

The trial at BANI will be led by an Arbitrator Council consisting of 3 arbitrators. Both the Petitioner and the Respondent are each given 7 (seven) days and an opportunity to appoint 1 arbitrator who is trusted to have sufficient knowledge, experience and background regarding the existing problems. If the Assembly consists of three arbitrators, in the event that the parties have appointed their respective arbitrators, then the Chairperson of BANI appoints an arbitrator who will preside over the Assembly.

Before the trial begins, the Arbitrator has first studied the problem in the case that he will handle from the request and answer that the parties have submitted before the first trial. So that the arbitrators have understood the problem that is being examined not only in terms of law but also from a technical point of view. So that the inspection process can run smoothly and dynamically.

(6) the freedom of the parties to choose who will be the arbitrator. Things like this cannot be found in other general courts. in the arbitration tribunal, the parties to the dispute can choose the arbitrator according to the background of the dispute being faced. This is so that the process of resolving disputes with different domains can be handled by arbitrators in accordance with the realm of the related 
disputes. Therefore, an arbitrator does not always have to have a legal background, there are economics, finance, taxation, shipping, criminal, and all kinds. So usually, the arbitrator has an assembly consisting of various backgrounds of expertise.

(7) The existence of arbitrators in settling disputes comes from the choice of the parties themselves, so that they must be able to choose arbier who can be neutral so that there is no conflict of interest in the resolution of disputes. The arbitrator is the duty and function to fight for the truth objectively. He must be able to meet the interests of the parties to the dispute,

(8) Opportunities for Parties to Keep Collaborating (Business) After the Case Is Disconnected, and this is very important for banks and business people, its relation to the market and others (Gerrard, 1997: 80). Settlement through an arbitration process can provide the best solution. Although it is not always a win win solution, at least in cases for companies that have a dispute with a government-owned company, a decision can be reached that provides legal certainty when a dispute arises due to differences in interpretation. This is to remember, without any certainty of interpretation will make doubt the movement of the implementation of future cooperation for both parties. Not to mention the possibility of an audit result that can provide sanctions. Thus, in some cases of arbitration that we have handled, the business relationship between the client and the opposing party, or the counter part, remains well established and the cooperation contract continues.

After the decision is made, the existing contracts between the parties continue, because the purpose is not to break the existing contract. But to solve existing problems. Based on our experience, this only happens in arbitration, because the main points of the parties are to find a way out of the existing problems so that they are profitable (win-win solution). In contrast to the settlement through the general court, where the parties generally aim to only terminate or cancel the contract to claim compensation.

This makes arbitration the best choice for business people to resolve disputes between the parties while promoting good relations for the future. Moreover, due to the nature of closed arbitration settlement, the confidentiality of the case that runs is maintained. So, the parties do not become anxious about public views, after the dispute then do business again. Settlement outside the court with a place and method determined by these parties by Galanter (1981: 129) see also Triana (2018: 49) referred to as justice in many rooms. This means that justice 
can not only be obtained in court, but in various spaces in a different way from the Court

\section{Arbitration Clause}

According to Black's Law Dictionary: “Arbitration. An arrangement for taking abiding by the judgment of selected persons in some disputed matter, instead of carrying it out to establish tribunals of justice, and is intended to avoid the formalities, the delay, the expense and vexation of ordinary litigation ". Whereas based on Law No.30 of 1999 Article 1 paragraph (1) Law No. 30 of 1999 on Arbitration and Alternative Dispute Resolution (UUAPS) “ Arbitration is a way of resolving civil disputes outside the general court based on an arbitration agreement made in writing by parties who dispute ". Furthermore, this is further reinforced in Law Number 48 of 2009 concerning Judicial Power, Article 59 paragraph (1) of Law No.48 of 2009 "Arbitration is a way of resolving a civil dispute outside the court based on an arbitration agreement made in writing by the the disputing party.

Based on the two laws above, it can be known, the first substance that arbitration is a way of resolving civil disputes because it is impossible for arbitration to be applied to criminal disputes or administrative disputes. according to Article 5 paragraph 1 of Law Number 30 of 1999 UUAPS is only a dispute in the field of trade and regarding rights which according to law and legislation are fully controlled by the parties to the dispute. The activities in the trade sector include: commerce, banking, finance, investment, industry and intellectual property rights. Meanwhile Article 5 (2) of the Arbitration Law provides a negative formulation that disputes that are considered not to be resolved through arbitration are disputes which according to the law cannot be held peace as stipulated in the KUH Perdata (Civil Law) Book III eighteenth chapter Article 1851 to 1854 .

Furthermore, the second substance which is explained again in the definition of arbitration in the invitation law is that the Arbitration is a way of resolving civil disputes outside the court, be it the General Court, or the Special Court such as the Religious Court. In addition, the explanation of Article 59 paragraph (1) of Law No.48 of 2009 makes it even clearer that what is accepted by this arbitration includes Sharia Arbitration. 
The third substance as stated in the definition of arbitration above, the settlement of a dispute in an abritase manner is based on an agreement, namely what is referred to as the arbitration agreement. The Law No. 30 of 1999 on Arbitration and Alternative Dispute Resolution (UUAPS) define the arbitration agreement as follows: Article 1 number (3) UUAAPS: An arbitration agreement is an agreement in the form of an arbitration clause stated in a written agreement made by the parties before a dispute arises, or a separate arbitration agreement made parties after a dispute arises.

The life of an arbitration is an arbitration agreement. the arbitration agreement will determine whether a dispute can be resolved through arbitration, where it is settled, which law is used, and so on. The arbitration agreement can be independent or separate from the pokonya agreement. There is no requirement in the Arbitration Law that determines the arbitration agreement must be made in a notary deed.

From the formal juridical definition of Law No. 30 of 1999 on Arbitration and Alternative Dispute Resolution, it can be seen that the arbitration agreement can be one of the two things below (Setiadi, 2018: 16-20): First: An arbitration agreement can be a clause stated in a written agreement made by the parties before a dispute arises or commonly referred to as the "Arbitration Clause" or "Arbitration Clause". The arbitration agreement in the form of an arbitration clause is often referred to as pactum de compromittendo. Second: An arbitration agreement can be a separate agreement made by the parties after a dispute arises or commonly referred to as the arbitration agreement in the narrow sense or an arbitration agreement. This type of agreement by some Indonesian writers is often referred to as a compromise deed, which is a special agreement made after a dispute has occurred to regulate how to file a dispute that has occurred to an arbiter or referee to be resolved.

The arbitration agreement plays a very important role in determining the settlement of disputes by arbitration. There is no arbitration without a valid arbitration agreement. Alan Redfern, Martin Hunter and Nigel Blackaby (Redfern and Hunter, 2005: 640) put forward the importance of the arbitration agreement as follows: "An arbitration agreement does not merely serve as evidence for the consent of the parties to arbitration and to establish the obligation to arbitrate. It is the basic source of the powers of the arbitral tribunal". 
For the validity of an arbitration agreement (whether in the form of an arbitration clause or a compromise deed), the following requirements are required (Adolf, 2015: 121) (1). Agreement from the parties that made it: The parties' agreement is the main element of an arbitration agreement. This means that the parties to the arbitration agreement must agree or agree that the dispute between them will be resolved arbitrarily, both institutional arbitration and ad hoc arbitration. (2) The ability to act from the parties that make it: The parties that make arbitration must be able to act in accordance with applicable legal provisions, for example if measured in the legal provisions of "people" then determined maturity or married, whereas if the parties are legal entities then Legal entity's acting skills can be measured from the statute of the legal entity. (3). The specific object or subject: The object of the arbitration agreement, in essence is the dispute between the parties, both the dispute that will occur and what has happened, which is agreed upon by the arbitration settlement. (4). The halal cause: this relates to arbitration, namely that which in principle can be resolved by means of arbitration namely civil disputes in the field of trade / economics. (5). Loaded in a document signed: That the arbitration agreement must be contained in a document signed by the parties.

The existence of a valid arbitration agreement will give legal consequences to prevent one of the parties who have agreed on an arbitration agreement to seek settlement of the dispute in the Court. These legal consequences are usually implemented in the form of the right to file exceptions to absolute authority over a lawsuit or case filed with the Court whose parties have been bound by an arbitration agreement. This means that if the parties have been bound by an arbitration agreement, then if one of the parties submits a lawsuit to the Court, the other party can submit an exception or deny the absolute authority of the Court on the grounds that the Court is not authorized to try the case, because the parties have been bound arbitration agreement. If the exception can be justified, namely if the parties are truly bound by the arbitration agreement, the Court must declare itself not authorized to try the dispute.

This prevention is provided because the arbitration agreement is independent agreement and is separate from the agreement or 
commercial contract (the principal agreement), so theoretically and practically it is possible for one of the parties to the arbitration agreement to breach of contract with another party in the agreement the arbitration. In countries that hold a common law system, if one of the parties bound by the arbitration agreement is in breach of the arbitration agreement by taking a lawsuit to the Court which is deemed authorized the party who does not undertake the contract violation in arbitration can submit an application to the arbitrator the assembly that is examining the arbitration case or to the Court whose jurisdiction covers the place of arbitration in order to issue what is called an anti suit injunction (Harahap, 2001: 29).

Anti-suit injection is an order in the form of a ban issued by the arbitrator or the arbitral tribunal or the Court which prohibits one of the parties to an arbitration agreement from filing a lawsuit to the Court or continuing a lawsuit that is proceeding in the Court. With this anti suit injunction, it is expected that the parties will be subject to the arbitration agreement and carry out the arbitration process in accordance with what has been agreed in the arbitration agreement. In the event that an anti suit injunction is issued by the Court, violation of the prohibition will result in contempt of court against the Court. This anti-suit injunction law in common law countries is felt to be effective enough to force parties to comply with the arbitration agreement agreed upon.

\section{Arbitration Clause in the Development of Sharia Economics}

Sharia Arbitration has experienced significant developments both in terms of legal and institutional regulations. Law No.48 of 2009, article 59 paragraph (1) of Law No. 48 of 2009, expressly states that "What is meant by" arbitration "in this provision includes sharia arbitration, so that there is no doubt that arbitration as referred to in the Arbitration Act and Alternative Dispute Settlement (UUAPS No. 30 years 1999) is a way of resolving civil disputes outside the court, both General and Religious Courts, and UUAPS is the only law that regulates arbitration as well as sharia arbitration.

In a civil case, the Arbitration Act and Alternative Dispute Resolution (UUAPS) allow disputing parties to resolve their civil disputes outside the court, namely by way of arbitration if the parties want it. Therefore UUAPS requires that if the parties want the resolution of civil disputes 
resolved outside the court, then the will must be stated in an agreement made in writing or known as the arbitration agreement. Provisions which require the existence of an arbitration agreement are compelling legal provisions (dwingend regels or mandatory rules) that cannot be deviated. Thus, the arbitration agreement is an absolute requirement for the execution of civil dispute by arbitration.

The arbitration agreement occurs as the implementation of the parties' freedom to determine the settlement of a dispute, from an agreement that may arise in the future to be resolved through an arbitration forum. The freedom of the parties in choosing arbitration as a dispute resolution forum must be formulated in an arbitration agreement on the basis of an agreement to fulfill the legal requirements of the agreement. Therefore, the implementation of arbitration agreements based on the freedom of contract will be valid for the parties if it has been agreed and consequently they must obey the agreement in good faith.

In Islamic law, freedom of contract is called al-hurriyah. This principle is a fundamental and fundamental principle in Islamic treaty law. The parties are free to make and carry out contracts with anyone, and any type of contract. The parties were also given the freedom to enter any clauses, including the dispute resolution mechanism that does not conflict with the provisions of Islamic law (Arifin,2016:382).

Freedom of contract in Islamic law is based on Al-Quran, AlMaidah (5): 1, "you who believe, fulfill the contracts. This provision is the basis for a justification for making an arbitration agreement in a contract made based on the freedom of contract. The freedom of contracting this in Islamic law is not only related to other parties who enter into an agreement in man- made covenant law, but also includes an agreement of a servant to God. Every contract that is carried out will certainly be held accountable, as stated in Al Quran Al-Israk (17): $34, \ldots$ "and fulfill the promise, in fact the promise must be held accountable ..." That is, the agreement or contract made is binding and must be fulfilled by the parties (pacta sun servanda), and will be held accountable by God.

To form a valid arbitration contract, in accordance with the provisions of Islamic law, must fulfill the terms and conditions of the contract. Pillars of contract are: (1). The parties' agreement, 
(2). Subject of contract (Contracting parties), (3). Contract object and (4). The purpose of the contract. Completing the four pillars referred to as elements of the contract, the contract must also fulfill several conditions, namely: (1). Terms of occurrence or formation of a contract, (2). Terms of validity of the contract, (3). Terms of implementation or the effect of the contract, and (4). Terms of certainty or binding the contract.

Law Number 30 of 1999 concerning Arbitration and Alternative Dispute Resolution confirms that an arbitration agreement must be made in writing. This is in accordance with Islamic Law, as shown in the Qur'an. Al Baqarah (2) 283 which also implies, that muamalah relations be made in writing (Although this paragraph is intended for transactions in the form of credit). Arrangement of making the arbitration agreement in writing becomes a compelling provision intended for the good of the parties who carry out the contract, and will be very useful when a dispute arises in the future.

In general, arbitral bodies recommend a form of standard arbitration clause that can be used by the parties to the agreement, if the parties intend to show certain arbitration bodies to administer the dispute and arbitration is carried out using the procedure of the arbitration body. BANI (Indonesian National Arbitration Board), for example, has the following version of the arbitration clause as follows : "All disputes arising from this contract shall be binding and be finally settled under the administrative and procedural Rules of BANI (Arbitration of Indonesian National Arbitration Board ) by arbitrators appointed in accordance with said rules "

While in the sharia agreement or aqad agreement, the arbitration clause used is usually very simple, for example by containing the following article on dispute resolution (Hidayati, 2015: 173)

1. In the event of a difference of opinion or interpretation of matters listed in this agreement or disputes in the implementation of the parties agree to settle it in consultation to reach a consensus.

2. If consensus has been sought, but differences of opinion or interpretation, disputes or disputes cannot be resolved by both parties, the parties agree, and hereby pledge and bind one another to settle through the National Sharia Arbitration Board ( Basyarnas) according to the procedure of the procedure in force within the Arbitration Board 
3. The parties agree and hereby bind themselves to one another, that legal opinions (legal opinions and or decisions determined by the National Sharia Arbitration Board (Basyarnas) are final and binding .

In fact the formulation of an arbitration clause in a contract does not always have to be as simple as the clause commonly found in the standard agreements contained in Islamic banking, in large business agreements and involving many parties, both domestic and foreign companies, the arbitration clause must be accommodate the interests of the parties, who of course have different backgrounds both social and legal.

BANI Sovereign version, recommends the arbitration clause below to include in the contract or agreement if the parties intend to submit a dispute that will arise from the contract to BANI, as follows:
"All disputes arising from and or in connection with this agreement and or the implementation of this agreement, which cannot be resolved by deliberation, whether regarding breach of contract or unlawful conduct, including regarding termination and / or validity of this agreement, will be settled and terminated through Arbitration in Jakarta at the Indonesian National Arbitration Board (BANI) which is a legal entity based on the Decree of the Minister of Justice and Human Rights of the Republic of Indonesia No. AHU-0064837.AH.01.07. YEAR 2016 dated June 20, 2016, in an Arbitration Tribunal totaling 3 (three) Arbitrators and using Indonesian Language, based on BANI Regulations, the Arbitration Award is final and binding.

While SIAC (Singapore International Arbitration Center) recommends the SIAC version of the arbitration clause to be included in the contract if the parties intend to resolve the dispute through arbitration using the SIAC Rules and administered by SIAC. "Any dispute arising out of or in connection with this contract, including any question regarding its existence, validity or termination, shall be referred to and finally resolved by arbitration arministered by the Singapore International Arbitration Centre (SIAC) in accordance with the Arbitration Rules of the Singapore International Arbitration Centre (SIAC Rules) for the time being in force, which rules are deemed to be incorporated by reference in this clause". The clause can also be added with several provisions to clarify, as follows:

"The seat of the arbitration shall be

The Tribunal shall consist of arbitrator(s)

The language of the arbitration shall be 
For agreements involving foreign parties, or companies that are in Indonesia but foreign property, the parties are free to agree, the following matters: Determine the procedural law that will be used in the examination of disputes insofar as it does not conflict with the Law, Determine the use of Arbitration institutions (National or International), and also can determine which legal choices will be used (Cut Memi, 2017: 37)

What is interesting and distinguishes the arbitration clause of the Shariah agreement or BANI with the SIAC arbitration clause is that in the arbitase clause the Sharia agreement or BANI includes peace efforts as the main thing that must be carried out before arbitration, this is in accordance with the teachings of Islam that prioritize peace in every problem among Muslims, this peaceful method is taught in Sulh or Islah, as well as in the BANI institution (Indonesian National Arbitration Board) as a national arbitration institution that upholds Indonesian culture, resolves disputes or problems by means of consensus first. In practice in arbitration, the process for carrying out deliberation or prayer is in the form of negotiation or mediation at the first stage of the Arbitration process.

If in the process of mediation or negotiation, the word consensus is not found, at least this stage reduces hostility between the parties. The next step is to carry out the Arbitration stage. In principle, the arbitration award is so pronounced that it will apply and bind the parties to the dispute, and the parties to the arbitration dispute must implement the arbitral award voluntarily (Oseni, 2011: 5).

In practice after the arbitration award has been sent to the parties, the winning party will give a unilateral subpoena or warning to the losing party in order to carry out the arbitration award voluntarily within the specified period specified in the subpoena or the letter of reprimand. This time period varies in practice, but often the winning party gives a 14 (fourteen) day grace period in the subpoena or the intended warning letter.

Often reprimand or somasi (legal notice) is carried out more than once or even three times, with the consideration of giving enough time to the losing party to carry out voluntarily. This step of giving a subpoena or reprimand is very important if later the losing party does not want to carry out the arbitral award voluntarily, this somasi (legal notice) or 
reprimand can be used as evidence in submitting an application for the implementation of the arbitral award to the Chairperson of the Court.

For sharia disputes that use sharia arbitration, if the reprimand or somasi (legal notice) remains not implemented by the losing party, then it can be guided by the Supreme Court Regulation (Perma) No. 14 of 2016 concerning Procedures for Completion of Sharia Economic Cases. Supreme Court Regulation (Perma) No. 14 This serves as a guideline for Judges in the Religious Courts in resolving Islamic economic disputes. Interestingly, Perma No. 14 of 2016 also regulates the execution of sharia arbitration decisions. Article 13 paragraph (2) \& (3) Perma No. 14 of 2016 states (2) "The implementation of sharia arbitration decisions and their cancellations is carried out by a court within the religious court", (3) The procedure for the implementation of decisions as referred to in paragraph (2) refers to Law Number 30 of 1999 concerning Arbitration and Alternative Dispute Settlement.

Based on Article 13 paragraph (2) \& (3) of the Supreme Court Regulation (Perma) No. 14 of 2016 it can be understood that the authority to execute a Sharia arbitration award is again the authority of the Religious Court. This is in accordance with the Supreme Court Circular Letter No. 08 of 2010 which revoked the Supreme Court Circular Letter 8 of 2008 concerning the Execution of the Decision of the Sharia Arbitration Board. Whereas since the enactment of Law No.48 of 2009 concerning Judicial Power, there is no longer a dualism in the execution of arbitral decisions, where all sharia arbitration decisions, their executions are carried out by "orders" or orders for implementation of the Chairperson of the Religious Courts. In addition, the authority to execute the Sharia arbitration award by Supreme Court Regulation (Perma) No. was granted. 14 of 2016 strengthens the legitimacy of religious courts as the only court institution authorized to settle sharia economic disputes (Annas, 2017: 5-10).

In the case of execution as in Supreme Court Regulation (Perma) No. 14 of 2016 concerning Procedures for Completion of Sharia Economic Cases, arbitration dispute resolution cannot request assistance from the authority of the Religious Courts to force parties to lose automatically, but coercion can be carried out if the winning party enters into an arbitration system in the arbitration decision by make it the same or equivalent to the decision of the Religious Court which has permanent legal force. This is 
where the importance of the institution of the "order" of the Chairperson of the Court or the "execution order" of the Chairperson of the Court is regulated in the Arbitration Act and Alternative Dispute Settlement (UUAPS), where the principle will give legitimacy to the arbitration award which was outside the court system to enter into the court system so that it can be enforced by or through the court.

Based on the description above, it is very important that Sharia financial institutions or sharia business institutions create arbitration clauses in each agreement they make. So that when a default occurs, the settlement of the Sharia arbitration dispute can be done outside the Religious Court, but can have the same legal force as the Religious Court. Forcing power or execution can be carried out on the orders of the Chairperson of the Religious Court, if necessary.

Institutionally, in Indonesia there is a National Sharia Arbitration Board (BASYARNAS). The regulation on alternative dispute resolution or arbitration in most of its principles adopts the United Nations Commission on UNCITRAL International Trade Law Model which is then adapted to sharia principles. With the development of the current Islamic economy, support for dispute resolution institutions can be a support in increasing Islamic economic activity.

The role of the Arbitrator in the settlement of disputes is the same as the role of the Judge in the district court, namely examining, adjudicating and deciding the case / dispute filed with him. In terms of its type, tahkim or arbitration can be divided into three types, including (Harahap, 2001: 57):

1. National (general) Arbitration. National Arbitration is a general arbitration and can be used to resolve various types of conflicts due to all types of civil contracts and subject to national law in a country. Indonesia has authorized or has a national arbitration institution called the Indonesian National Arbitration Board (BANI). BANI was formed based on Law No. 30 of 1999 concerning arbitration and alternative dispute resolution. BANI can resolve conflicts that are based on contracts and are subject to Indonesian National Law.

2. Special Arbitration. Special Arbitration is an arbitration that resolves conflicts specifically in certain fields such as sharia economics or finance, industry, sports and so on. Special arbitration is more specific to sharia arbitration that resolves disputes in the field of sharia economics which includes economic activities such as sharia banks, sharia insurance, 
sharia reinsurance, sharia mutual funds, sharia bonds, sharia financing, sharia pawnshops, sharia businesses and so on. In Indonesia there is BASYARNAS (National Sharia Arbitration Board) which is a body under the Indonesian Ulama Council (MUI).

3. International Arbitration. Arbitration to resolve conflicts based on international contracts and subject to international law. That is the process of resolving disputes using arbitration outside the territory of the Republic of Indonesia, with the reason to avoid uncertainty relating to litigation in national courts.

While the existence of the arbitration decision period consists of two types, namely:

a. Ad hoc arbitration or temporary arbitration. Ad hoc arbitration is an arbitration that is formed specifically to be able to resolve or decide on certain disputes. Therefore the nature of ad hoc arbitration is incidental, where its position and existence are only to serve and decide on a particular dispute case, if it has resolved the dispute by case, then the existence and function of the ad hoc arbitration vanishes and ends automatically. In general, ad-hoc arbitration is determined based on an agreement stating the appointment of the arbitral tribunal and the implementation procedure agreed upon by the parties. The use of Adhoc arbitration needs to be mentioned in an arbitration clause.

b. Institutional Arbitration, Institutional Arbitration is an institution or arbitration body that is permanently managed by various arbitration bodies based on the rules they set themselves. So that institutional arbitration remains forever and does not disband, even though the dispute that has been resolved has been decided. At present the institution is known by various arbitration rules issued by arbitration bodies such as the Indonesian National Arbitration Board (BANI) in Indonesia, or internationally such as The Rules of Arbitration from the International Chamber of Commerce (ICC) in Paris, The Arbitration Rules from the International Center for Settlement of Investment Disputes (ICSID) in Washington.

From the various of arbitration bodies, UNCITRAL (The United Nations Commission on International Trade Law) as a United Nations body that manages international trade law continues to seek harmonization to create uniform Arbitration law procedures and implementation to facilitate the settlement of conventional business or sharia business disputes. 


\section{Conclusion}

At present, the sharia economic has developed into a national and international business. This development was followed by all the devices, including the dispute resolution system. Dispute resolution arbitrarily has many advantages over litigation (Court), shorter time, more simple proceedings, arbiteir who is experienced in his field, the results of final arbitration decisions and bindings and more importantly how to resolve disputes with arbitration does not cause hostility, so it is very open to re-establish business together. Institutionally, arbitration exists in every country, and there is a special arbitration for the settlement of sharia economics, in Indonesia known as BASYARNAS . (National Sharia Arbitration Board) For settlement of disputes using an arbitration event, an arbitration clause must be made separate from the commercial agreement (principal agreement). The arbitration clause is an agreement that binds both parties, that if at any time a problem arises in the principal agreement it will be resolved by arbitration. The power of the arbitration clause will give legal consequences to prevent one of the parties who have agreed on an arbitration agreement to seek resolution of the dispute in the Court. These legal consequences are usually implemented in the form of the right to file exceptions to absolute authority over a lawsuit or case filed with the Court whose parties have been bound by an arbitration agreement.

The arbitration agreement (arbitration clause) becomes very important for the smooth running of the sharia economic. Arbitration Agreement in Islam, always preceded by a sentence (point) of deliberative deliberation efforts in advance, this method is very highly recommended in Islam, namely in the case of muamalah disputes that arise will be more important if resolved through peaceful means (tasaluh / Suluh). For this reason, the parties should prioritize peace efforts compared to litigation (court). The trial was taken as the last resort by the parties in resolving the dispute. Arbitration in Islamic law has long been known as a form of dispute resolution known as tahkim. Tahkim is to appoint someone as a referee or peacemaker. by two or more people who are in dispute in order to settle the case which they have peacefully divided. While the term now tahkim can be translated as arbitration, and the person acting as the referee is called arbitrator or hakam.[] 


\section{References}

Adolf. Huala, Dasar-Dasar, Prisip dan Filosofi Arbitrase. Jakarta: Keni Media, Cetakan ke-2 .2015.

Annas, Syaiful, Kewenangan Eksekusi Putusan Basyarnas (Sebuah Kajian Terhadap Pasal 59 ayat (3) UU Kekuasaan Kehakiman Dan PascaLahirnya PERMA Nomor 14 Tahun 2016). http://pta-banjarmasin.go.id/kewenangan-eksekusiputusan-basyarnas-syaiful-annas-hakim-pa-batulicin-kalsel/ posted 10 juli 2017. (Downloaded 0ktober 3, 2018).

Arifin. Muhammad, Arbitrase Syariah Sebagai Pilihan Forum Penyelesaian Sengketa Perbankan Syariah. Yogyakarta: Pustaka Pelajar. 2016

Asnawi, M.Natsir.Menyoal Kompetensi Peradilan Agama dalam Menyelesaikan Perkara Ekonomi Syariah. Jakarta: Media Badilag, 2011.

Cut Memi, Arbitrase Komersial Internasional Penerapan Klausul Dalam Putusan Pengadilan Negeri, Jakarta: sinar Grafika, Cetakan Pertama, 2017.

Galanter Marck. Justice in Many Rooms : Court, Privat Ordering and Indigenous Law. Article in The Journal of Legal Pluralism. No.19.Thn 1981.

Gerrard P and J.B. Cunningham, Islamic Banking: A Study in Singapore, International Journal of Bank Marketing Vol.15 No.9 1997.

Hidayati Reni, Eksistensi Klausula Arbitrase dalam Penentuan Penyelesaian Sengketa Syariah. Mazahib Jurnal Pemikiran Hukum Islam .Vol.XIV. No.2 Desember. 2015. (ISSN-1829-9067. EISSN-2460-6588) 2015.

Khalidah Dahlan Nur. Arbitration and Mediation Method Applied to Islamic Finance Conflicts in Malaysia. Journal of Social Science Research. Vol 6 No.1. Malaysia. 2012.

Mikhail Kartuzov, Advantages and Disadvantages of International Commercial Arbitration in Comparison to Litigation and Other Means of Dispute resolution. Europian Political and law Discourse, Vol.2 Issue 3 2015- issn 2336-5439

Manik Saut Maruli Tua, Yaswirman, Busra Azhari dan Ikhwan, Penyelesaian Sengketa Ekonomi Syariah Melalui Pengadilan Khusus Ekonomi Syariah di Lingkungan Peradilan Agama, Ahkam. Jurnal Ilmu Syariah. Vol.17 Nomor 2. Tahun 2017. UIN Syarif Hidayatullah, Jakarta. 2017.

Oseni A. Umar and Abu Umar Faruq Ahmad, Dispute Resolution in Islamic Finance: A Case Analysis Of Malaysia, Article online in 8th International Conference on Islamic Economics and Finance .December,2011

Mark Van Hoecke, Methodologies Of Legal Research (Which Kind of Method For What Kind of Dicipline), Europian Academy of Legal Theory .Vol:9. Oxford and Portland, Oregon-2011.

Alan Redfern, Martin Hunter and Nigel Blackaby Law and Practice of International Commercial Arbitration, Arbitration International Journal, Volume 21, Issue 4, 1 December, Oxford University, 2005.

Rashid, Syed Khalid. "Alternative Dispute Resolution in the Context of Islamic Law."The Vindobona Journal of International Commercial Law and Arbitration, 2004.

Setiadi. A. Putusan Arbitrase Nasional dan International Dalam Perspektif Hukum 
Indonesia. Penerbit PT.Ajang Bisnis Global - Jakarta Indonesia: Cetakan Pertama-Februari 2018.

Strauss and J Corbin, Busir, Qualitative Research, Grounded Theory Procedure and Techniques, London: Sage Publication, 1990.

Triana, Nita. Reconstructing Sharia Economic Dispute Resolution Based on Indonesian Muslim Society Culture. Ijtimāiyya: Journal of Muslim Society Research, Vol. 2 (1), 2017.

Triana, Nita. and Deddy Purwinto, Justice in Many Rooms in Sharia Banking Dispute Resolution To Achieve Justice. Diponegoro Law Review. Vol 3 (1), 2018.

Wahed.Hais. Sulh: Its Application in Malaysia. Journal of Humanities and Social Science (IOSR_JHSS) Vol 20.Issue 6 Ver 11 June 2015.

Yaacob, Hakimah. "Alternative Dispute Resolution in Islamic Finance: Legal Challenges and the Way Forward." ISRA International Journal of Islamic Finance 1, no. 1 (2009).

Yahya Harahap, Arbitrase Ditinjau dari Reglemen Acara Perdata (Rv), Peraturan Prosedur BANI, International Centre for the Settlement of Investment Disputes (ICSID), UNCITRAL Arbitration Rules, Convention on the Recognition and Enforcement of Foreign Arbitral Award, Perma No.1 Tahun 1990, Jakarta: Sinar Grafika, Edisi Kedua, Cetakan Pertama 2001.

Zahraa, Mahdi, and Nora Abdul Hak. "Tahkim (Arbitration) in Islamic Law within the Context of Family Disputes."Arab Law Quarterly 20, no. 1 (2006).

Zuhaili Wahbah, Al Figh al Islam wa Adillatuhu ( Juz IV Dar El Fikr, Damaskus Syria: 2005).

Undang-Undang Republik Indonesia Nomor 48 tahun 2009 tentang Kekuasaan Kehakiman (Republic of Indonesia. Law Number 48 of 2009 concerning Judicial Power).

Undang-Undang No.30 Tahun 1999 tentang Arbitrase dan Alternatif Penyelesaian Sengketa (Law No. 30 of 1999 concerning Arbitration and Alternative Dispute Resolution).

The United Nation Convention on the Recognition and Enforcement of Foreign Arbitral Award, Done in New York, 10 June 1958.

Nita Triana, Institut Agama Islam Negeri Purwokerto. Email: triananita@ymail.com 


\section{Mhliam}

AHKAM Jurnal Ilmu Syariah (ISSN: 1412-4734/E-ISSN: 2407-8646) is a periodical scientific journal published by Faculty of Sharia and Law of Syarif Hidayatullah State Islamic University Jakarta in collaboration with Indonesian Scientist and Sharia Scholar Association (HISSI). This journal specifically examines the science of sharia and obtains to present various results of current and eminence scientific research. The administrators receive articles as contributions Sharia and Islamic law disciplines from scientists, scholars, professionals, and researchers to be published and disseminated. The article will be situated in a selection mechanism, a review of proved reders, and a strict editing process. All articles published in this Journal are based on the views of the authors, but they do not represent the authors' journals or affiliated institutions.

AHKAM has been accredited based on the determination of Director General of Research Reinforcement and Development, Research, and Technology Ministry of Higher Education of Republic of Indonesia, No. 36/a/E/KPT/2016 (valid until 2021). 